\title{
A study of monetary integration in West Africa and its implications on trade in Africa
}

\author{
Rabnawaz Khan ${ }^{1 *}$ \\ ${ }^{1}$ School of Finance and Economics, Jiangsu University, Zhenjiang, Jiangsu, Zhenjiang \\ 212013, People's Republic of China.khan.rab@stmail.ujs.edu.cn
}

It shows the monetary investigation in west countries the big flow in economy by the gross value change effects, also the value of debt policy with debt management strategies to control the budgetary risk of long-term economy from sustainability. The intellectual policies of inflation, GDP, trade, and services and merchandise trade has effected on the West African country's monetary policies. The implication of trade by a lag of exchange rate indicators has a positive and significant effect. The estimated results reflect the dynamic implication of trade with liquidity and proper monitoring policies. The GDP, gross value (GVA), debt policies, equity of public administration, trade in service and merchandise trade is positive and significant, all are significant. We suggest the optimum control of liquidity with trade service policy recommendations in different countries. The research method was based on 5 countries from the 16 countries of western African and elaborated by their individual indicators with the least square method. The gross value of debts and public administration controlled the development aim of an entire state with strategic and planned environment for state and reduce the level of inflation in small and enterprise section and the results analyzed the policy makers implement planned in implication of trade with domestic currency and long run endogeneity. The results analyzed the monetary policies affecting the level of growth of an individual country.

Keywords: Monetary, west African countries, trade, economy

\section{1-INTRODUCTION}

We have increased the regional interaction the economy by the priority of free trade and growth. According to Negotiating Forum (NF) the Continental Free Trade Area (CFTA) is the path of trade and investment which convened for CFTA. The investment of incorporate of 53 African countries, represent 1 billion people with $\$ 3$ trillion GDP. The policy of implication of west African countries controlled by regional economic community (REC's) likewise West Economic and Monetary Union (WAEMU) is the main building block of achievement of free trade and monetary implication.(K. Ahmed, Bhattacharya, Shaikh, Ramzan, \& Ozturk, 2017; Aydin, 2019; Kong \& Khan, 2019; MengYunet al., 2018) The highest level of intraregional trade in West African countries is low when it compares to the level of a custom union trade in WAEMU and EU's with 25-60 percent. Fig 1. 


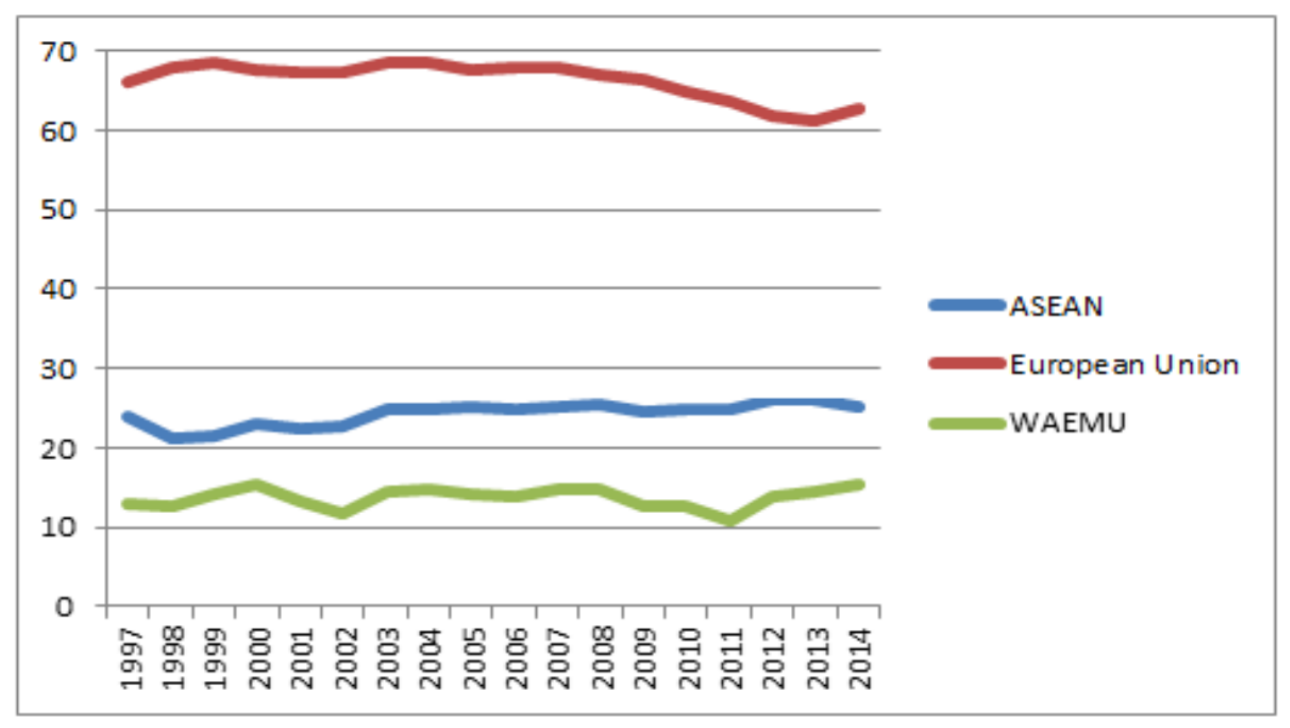

Figure 1: Intra-regional export for WEMU and ASEAN: Sources: UNCTA, 2015

Second the monetary policies and implication of trade is satiability of CFA franc zone in African countries in the term of macroeconomic.(Bekun, Emir, \& Sarkodie, 2019; Grossman $G$, 1995) The important issues some countries unstable and have taking weak attention of historically monetary institutional framework. However, the currencies depreciate in an external environment in the region's stability and legitimate to achieve the competitiveness of individual policies.

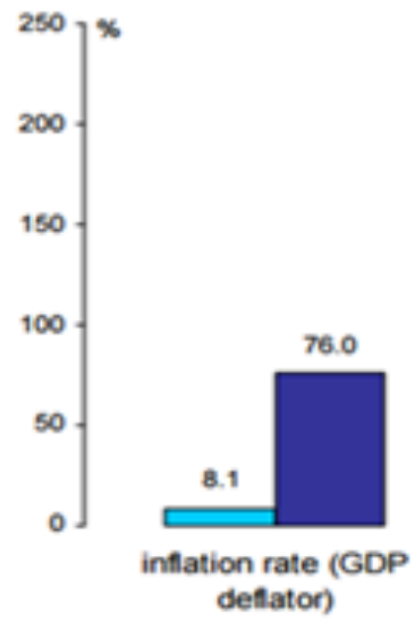

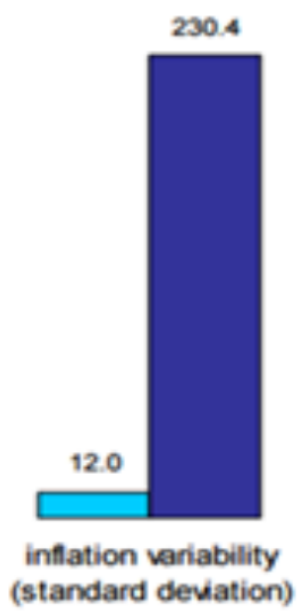

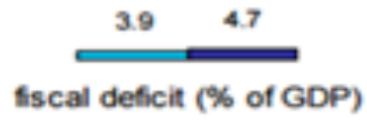

Figure 2: Franc stability, Sauce: Hallet, 2008

The global fixed exchange rate has benefited to foreign trade and taxation policies with achieving macroeconomic stability.(Abid, 2017; Dong, Wang, \& Guo, 2016; J. Du \& Zhang, 2018) The research showed the competitiveness challenges of GDP, trade services, and merchandise trade. The region economic communities in west countries have directly infect the economy by different strategic policies. 
The prior research implication based on economic development and south African country's economic policies and didn't mention th(Adom \& Kwakwa, 2014)e strategic policies regarding individual expect of foreign exchange rate, federal economic development trade and effected issues of GDP by CFA.(Adom \& Kwakwa, 2014) Therefore, this research is most import issues weighted and determined the strategic policy with CPIA debt policies, inflation, GDP deflator, trade services, trade (GDP),(G. Du, Liu, Lei, \& Huang, 2018; Riaz et al., 2018) merchandise trade and merchandise export. We base the second section of this research on the literature. We base the third section of this research on the method. $4^{\text {th }}$ section showed results and analysis and final section held with recommendation and conclusion.

\section{Literature}

We base prior research on implemented policies and strategic changes in sub-Saharan countries and highlighted the issues of economic development with individual effects. The convergence member of countries showed i.e. inflation, growth, per capita and currency union. (Coleman, 2010; Harvey \& Cushing, 2015)The common stock of macroeconomic policies more in under developing countries, which makes a common strategic policy for individual states.

Several theories in literature is showing the impact of policy regarding the monitoring policies, which created on asset prices, patents, development and growing of economy. The systematical approach of the theories effects on economics variables.(Button, Martini, Scotti, \& Volta, 2019; Osabutey \& Jackson, 2019) the first view is liquidity approach emphasized the increasing liquidity, asset prices increase, and it acts as a link in the transmission of liquidity assets on the economic activities with the wide range of development skills and determined policies of an individual government.(Bensassi \& Jarreau, 2019; Tsao et al., 2019) the other expects of low and stable inflation cause of lack of monitoring policies in stabilizing the high level of investment.(Keho, 2017; Yaya, Ling, Furuoka, Rose Ezeoke, \& Jacob, 2019) $2^{\text {nd }}$ the presented a dynamic equilibrium of monitoring policies based on the bubble in asset prices, in addition poor monetary policy design such as rate rules of sustainable long-term inflation. $3^{\text {rd }}$ the trend survey of effect on money and monetary policy on asset prices including the exchange rate the monetarist theory effects on uncertainty, government policies and economic growth. The highquality boom of assets price, growth of monetary supply and investment. (Asongu, Folarin, \& Biekpe, 2019; Mikayilov, Hasanov, \& Galeotti, 2018; Riaz et al., 2018)Therefore, the prior of research implicated the trade in big rule and hold the effect of a portfolio of a financial institution regarding huge investment and development policies. $4^{\text {th }}$ the policies of investment in a different channel by self-crating the huge gap in monetary policies, where the different price channel has tagging different prices level, credit ratio, exchange rate cause of the intellectual policies of inflation, GDP, trade and services and merchandise trade has effected on the west African countries monetary policies. The rate of a channel determined the effects on price and exchange rate (K. Ahmed, Bhattacharya, M., Shaikh, Z., Ramzan, M., \& Ozturk, I 2017; Cham, 2016). The exchange rate channel, other asset price channels, and the credit channel. Since the present study surveys the impact of monetary policy on the exchange rate, it determines the level of intensity in financing. (Al-Mulali, Ozturk, \& Solarin, 2016; Apergis \& Ozturk, 2015) .

The countries competitiveness will need to ensure the macroeconomic stability, which improved the business climate of trade, reduce the hard infrastructure stability and technology with transfer infrastructure gap.(Bo, 2015; Schwerhoff \& Sy, 2017; Zhao \& Kim, 2009) The investment of trade and strategic policies of economic development such as skills has increased agriculture as well with adept policies, training and extension program and build capabilities 
of domestic firms.(Acheampong, 2018 Awad \& Abugamos, 2017; Harvey \& Cushing, 2015) The structural transformation will require leverage of the ICT sector of productivity, financial tie and domestic macroeconomics frameworks.

\section{3-DATA, MODEL AND RESULTS}

We base this research paper research method on liner regression between gross value, CPIA debt policies, public administration with regional trade, GDP per capita, service in trade, trade of an individual,(Harding, 2007; Im, Pesaran, \& Shin, 2003; Zhang, Liao, \& Hao, 2018) merchandise trade and export of low income economy. It shows the stability of model the strategic policies, so the results conducted by the regression. In a first step unit root is taking for the stationary and non-stationary level of intimal of 5 countries from the 16 west African countries.

Table 1: Indicators

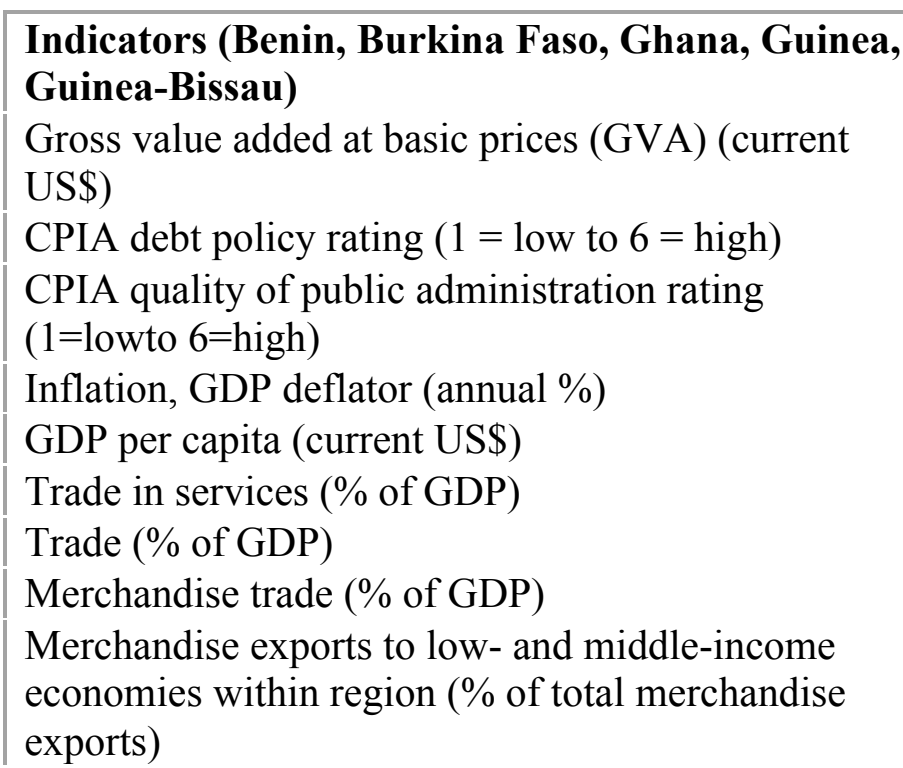

\section{Indicator WB}

NY.GDP.FCST.CD

IQ.CPA.DEBT.XQ

IQ.CPA.PADM.XQ

NY.GDP.DEFL.KD. ZG

NY.GDP.PCAP.CD

BG.GSR.NFSV.GD.ZS

NE.TRD.GNFS.ZS

TG.VAL.TOTL.GD.ZS

\section{Symbol}

GVA

CPIAD

CPIAQ

IGD

GDPPC

TS

TR

MTG

It indicates Table 1 the gross values of different indicators as per indicator codes. The strategic policies have been transit with 9 indicators and individually defined with the period of 19602018. However, the export level of merchandise. (Perron, 1988; Sinha \& Shahbaz, 2018)

\section{RESULTS AND ANALYSIS}

The results and analysis were analyzed using the liner method. In $1^{\text {st }}$ stage mean deviation of individual variables have been taking by skewness and Kurtosis, and the deviation analyzed by mean and standard deviation. The mean deviation is greater from the standard deviation. The individual indicator shows a significant effect on each individual variable(Cheng, Ren, Wang, \& Yan, 2019; Im et al., 2003; Saqib, Ahmad, \& Amezcua-Prieto, 2018; Zhao \& Kim, 2009). 
Table 2: Mean deviation

\begin{tabular}{|lrrrrrrrrr}
\hline & CPIA & CPIA & \multicolumn{1}{l}{ GDPP } & & & & & & \\
& \multicolumn{1}{l}{ D } & Q & C & GVA & IGD & MEL & MTG & TR & TS \\
Mean & 3.257 & 3.085 & 422.50 & $4.85 \mathrm{E}$ & 13.98 & 18.42 & 40.73 & 49.16 & 12.76 \\
& 143 & 714 & 22 & +09 & 841 & 137 & 666 & 242 & 901 \\
Median & 3.5 & 3 & 75 & +09 & 974 & 784 & 205 & 111 & 515 \\
Maximu & & & 2378.1 & $5.98 \mathrm{E}$ & 123.0 & 88.21 & 93.19 & 132.0 & 27.34 \\
m & 4.5 & 3.5 & 6 & +10 & 612 & 468 & 641 & 502 & 948 \\
& & & & & - & & & & \\
Minimu & & & 68.424 & $1.53 \mathrm{E}$ & 6.345 & 0.366 & 4.539 & 6.320 & 4.261 \\
m & 1 & 2 & 75 & +08 & 677 & 625 & 363 & 343 & 481 \\
Std. & 0.819 & 0.407 & 356.54 & $8.64 \mathrm{E}$ & 20.86 & 18.54 & 15.24 & 19.62 & 4.240 \\
Dev. & 786 & 995 & 33 & +09 & 788 & 171 & 254 & 153 & 764 \\
& - & - & & & & & & & \\
Skewnes & 0.740 & 0.644 & 2.6998 & 4.183 & 2.629 & 1.528 & 0.390 & 0.860 & 0.707 \\
S & 881 & 286 & 76 & 521 & 442 & 853 & 603 & 741 & 828 \\
& 2.598 & 2.662 & 12.432 & 22.12 & 10.78 & 4.856 & 3.599 & 4.834 & 4.132 \\
Kurtosis & 032 & 453 & 48 & 295 & 939 & 542 & 374 & 437 & 223 \\
& & & & & & & & & \\
Jarque- & 6.875 & 5.175 & 1274.8 & 4356. & 934.8 & 136.4 & 10.46 & 68.03 & 22.31 \\
Bera & 16 & 203 & 08 & 945 & 309 & 941 & 286 & 311 & 748 \\
Probabil & 0.032 & 0.075 & & & & & 0.005 & & 0.000 \\
ity & 142 & 2 & 0 & 0 & 0 & 0 & 346 & 0 & 014 \\
& & & & & & & & & \\
Sum & 228 & 216 & 8.1 & +12 & 056 & 87 & .8 & .9 & 348 \\
Sum Sq. & 46.37 & 11.48 & 32797 & $1.78 \mathrm{E}$ & 11017 & 87667 & 59942 & 98946 & 2913. \\
Dev. & 143 & 571 & 769 & +22 & 3.5 & .68 & .46 & .11 & 42 \\
Observa & & & & & & & & & \\
tions & 70 & 70 & 259 & 240 & 254 & 256 & 259 & 258 & 163
\end{tabular}

The given results of analysis have interoperated the distribution t-factors within between valuation.

Table 3: Covariance

Covariance Analysis:

Ordinary

Sample: 2005

2017

Included observations: 65

Balanced sample (listwise missing value

deletion)

Covariance 
t-

Statistic

Probabi

lity

CPIA CPIA GDPP

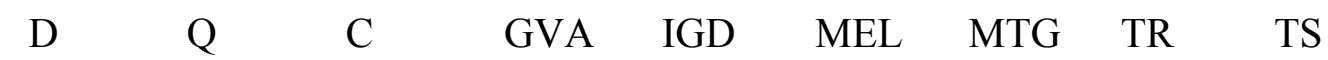
0.6855

CPIAD 62

$\begin{array}{rrr} & 0.2503 & 0.1530 \\ 55 & 18 \\ 9.6702 & \\ 79 & ----- \\ 0 & -----\end{array}$

GDPPC $\quad 80.139 \quad 66.126 \quad 17607$

$\begin{array}{rrr}73 & 7 & 1\end{array}$

$1.8815 \quad 3.4937$

$82 \quad 24 \quad----$

$0.06450 .0009 \quad-----$

$\begin{array}{rrrrr} & 3.87 \mathrm{E} & 3.29 \mathrm{E} & 5.63 \mathrm{E} & 1.97 \mathrm{E} \\ \text { GVA } & +09 & +09 & +12 & +20 \\ & 2.8009 & 5.9341 & 25.770 & \\ 63 & 68 & 55 & ----- \\ & 0.0068 & 0 & 0 & -----\end{array}$

IGD

$\begin{array}{lllll}0.3797 & 1.2224 & 1808.7 & 7.36 \mathrm{E} & 289.54\end{array}$

MEL

$\begin{array}{llllll}4.2129 & 1.0855 & 1030.4 & 3.36 \mathrm{E} & 16.188 & 302.97\end{array}$

$\begin{array}{rrrrr}-0.214 & 09 & 73 & 24 & ---- \\ 0.8312 & 0.1431 & 0.0417 & 0.0125 & ----\end{array}$

$0.83120 .1431 \quad 0.0417 \quad 0.0125 \quad----$

$\begin{array}{lllllll}3.3945 & 1.3640 & 1517.2 & 5.06 \mathrm{E} & 23.746 & 39.628 & 136.39\end{array}$

$\begin{array}{lrrrrrrr}\text { MTG } & 29 & 02 & 76 & +10 & 6 & 43 & 8\end{array}$

$\begin{array}{llllll}2.9756 & 2.4830 & 2.5844 & 2.5756 & 0.9552 & 1.5775\end{array}$

$\begin{array}{rrrrrrr}28 & 48 & 55 & 27 & 78 & 52 & ---- \\ 0.0041 & 0.0157 & 0.0121 & 0.0124 & 0.3431 & 0.1197 & ----\end{array}$


TR

$\begin{array}{rrrrrrrrrr} & 0.1203 & 0.8126 & 2488.3 & 7.59 \mathrm{E} & 63.690 & 17.782 & 152.64 & 272.77 & \\ \text { TR } & 82 & 54 & 52 & +10 & 64 & 76 & 74 & 75 & \\ & - & & & & & - & & & \\ & 0.0698 & 1.0063 & 3.0535 & 2.7489 & 1.8468 & 0.4919 & 10.274 & & \\ & 75 & 84 & 53 & 93 & 42 & 21 & 79 & ---- & \\ & 0.9445 & 0.3181 & 0.0033 & 0.0078 & 0.0695 & 0.6245 & 0 & ---- & \\ & & & & & & & & & \\ \text { TS } & 0.7175 & 0.4617 & 965.82 & 3.52 \mathrm{E} & 3.8742 & 9.6454 & 14.466 & 14.383 & 20.81 \\ & 98 & 66 & 95 & +10 & 5 & 11 & 73 & 65 & 71 \\ & 1.5356 & 2.1259 & 4.6376 & 5.2250 & 0.3965 & 0.9711 & 2.2389 & 1.5434 & \\ & 7 & 66 & 05 & 46 & 78 & 93 & 91 & 21 & ----- \\ & 0.1296 & 0.0374 & 0 & 0 & 0.693 & 0.3352 & 0.0287 & 0.1277 & ----\end{array}$

TS

Table 2 The significant relationships analyzed by the probability level of linear value, where the highest mean deviation is directly affect the monetary integration and implication of trade in African countries. the integration of value has been analyzed by the CPIAD, IGD and TS, where the gross value at the basic rate, inflation of GDP with trade service, merchandise trade, export and the quality of public administration in debt value and interpreted the monetary policies of Africa and implication on trade. Table 3

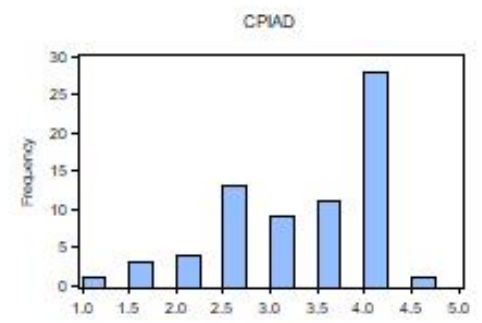

GVA

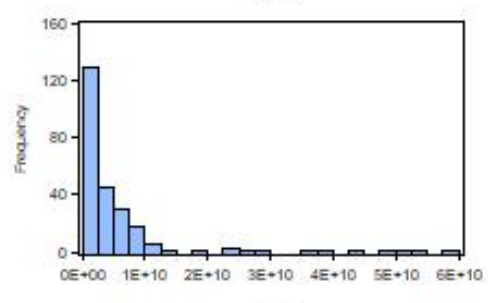

MTG

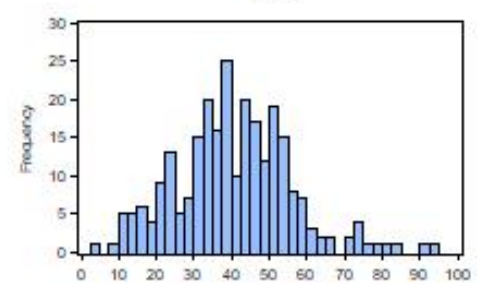

Figure 3: Mean and covariance
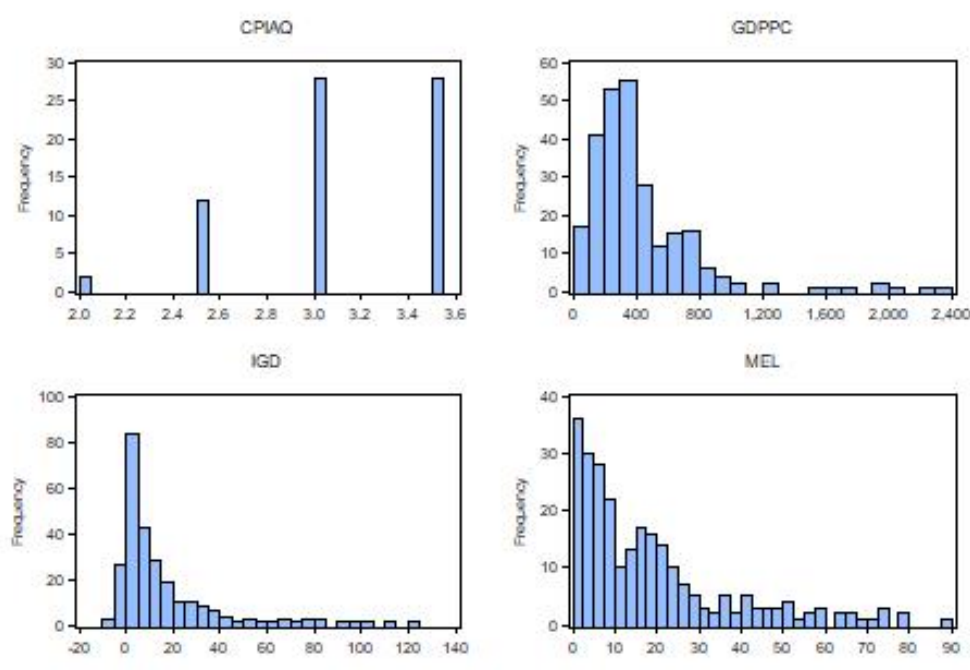

TR
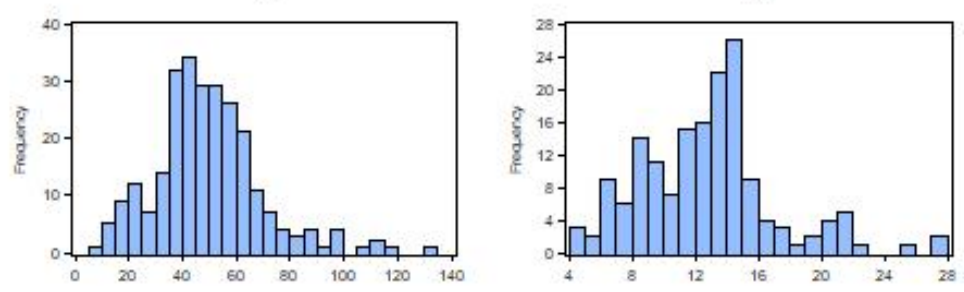

Table 4: Equity

Test for Equality of Variances Between Series 
Sample: 19602018

Included observations: 295

Method df Value Probability

Bartlett

8

59193.83

Levene $\quad(8,1820)$

75.12375

$(8,1820)$

43.85331

0

Brown-Forsythe

$$
(8,1820)
$$

Category Statistics

\begin{tabular}{lrrrr} 
& & & \multicolumn{1}{l}{ Mean Abs. } & \multicolumn{1}{l}{ Mean Abs. } \\
Variable & \multicolumn{1}{l}{ Count } & \multicolumn{1}{l}{ Std. Dev. } & Mean Diff. & \multicolumn{1}{l}{ Median Diff. } \\
CPIAD & 70 & 0.819786 & 0.706122 & 0.671429 \\
CPIAQ & 70 & 0.407995 & 0.331429 & 0.314286 \\
GDPPC & 259 & 356.5433 & 234.0249 & 218.1158 \\
GVA & 240 & $8.64 \mathrm{E}+09$ & $4.52 \mathrm{E}+09$ & $3.82 \mathrm{E}+09$ \\
IGD & 254 & 20.86788 & 13.7503 & 12.14635 \\
MEL & 256 & 18.54171 & 13.93338 & 13.22127 \\
MTG & 259 & 15.24254 & 11.83501 & 11.81549 \\
TR & 258 & 19.62153 & 14.58696 & 14.49539 \\
TS & 163 & 4.240764 & 3.173404 & 3.173305 \\
All & 1829 & $3.53 \mathrm{E}+09$ & $5.93 \mathrm{E}+08$ & $5.02 \mathrm{E}+08$
\end{tabular}

Bartlett weighted standard deviation: $3.13 \mathrm{e}+09$

\section{Error! Filename not specified.}

Figure 4: Least limitation

Fig 3 And the highest mean deviation of IGD and TS are indicated the highly effects of domestic trade in private sectors, its mean if the investment of individual countries will rise in private sector so effect on the monitoring policy. Table 4

Table 5: observation

Sample: 19602018

Included observations: 60

Autocorrelation Partial Correlation AC PAC Q-Stat Prob

\begin{tabular}{|c|c|c|c|c|c|c|}
\hline & $* *$ & & & & & \\
\hline$* *||$. & $\cdot{ }^{*}{ }^{*}$ & 1 & -0.223 & -0.223 & 3.1455 & 0.076 \\
\hline$*^{*}||$. & $\left.\cdot\right|_{* * 1}$ & 2 & -0.116 & -0.174 & 4.0065 & 0.135 \\
\hline$* *||$. & .1 & 3 & -0.224 & -0.318 & 7.2805 & 0.063 \\
\hline
\end{tabular}




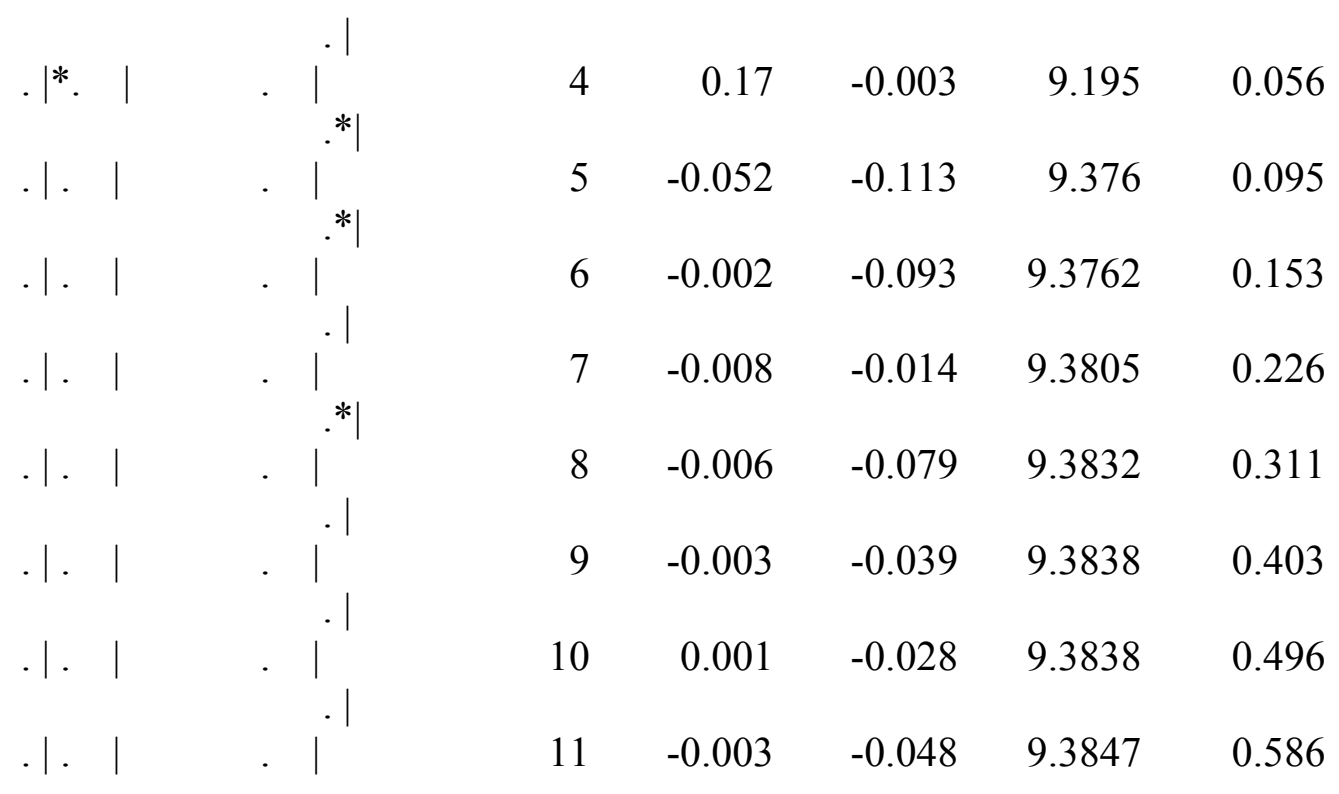

Table 5-6 is indicated the actual effects of fitted and residual effect by the level of actual intensity. The foreign trade computed by the debt policies and quality of public administration which is the part of monitoring policies. The trade service and merchandise trade with in economic growth with exports.

Table 7 is indicated the indicators different policies with sources of inflation and GDP per capita, the highlighted part of Trade service and investment, likewise, foreign investment under the stated law implement the rules and policies of CPIA quality and debit policies. Fig 4

Table 6: indicated observatin

Sample: 19602018

Included observations: 70

Correlations are asymptotically consistent approximations

CPIAD,CPIAQ(-

i)

CPIAD,CPIAQ $(+i) \quad$ i $\quad$ lag lead

$|* * * * * * * *|$
$|* * * * * * *|$
.$|* * * * * *|$
. $\mid * * * * *$
. $\mid * * * *$
. $\mid * * *$
. $\mid * * *$

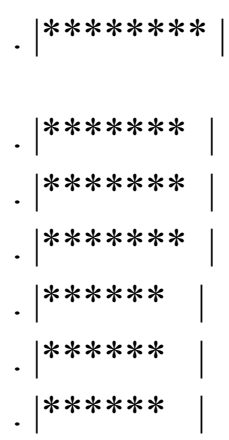

0

$0.7564 \quad 0.7564$

$\begin{array}{lll}1 & 0.6706 & 0.7213\end{array}$

$\begin{array}{lll}2 & 0.581 & 0.6862\end{array}$

$\begin{array}{lll}3 & 0.5078 & 0.6511\end{array}$

$\begin{array}{lll}4 & 0.4219 & 0.625\end{array}$

$\begin{array}{lll}5 & 0.3469 & 0.5988\end{array}$

$6 \quad 0.2846 \quad 0.5637$ 


\begin{tabular}{|c|c|c|c|c|}
\hline$\left.\right|^{* *}$ &. $\mid * * * * *$ & 7 & 0.2368 & 0.5305 \\
\hline$\left.\right|^{* *}$ &. $\mid * * * * *$ & 8 & 0.1927 & 0.5044 \\
\hline$\left.\right|^{* *}$ &. $\mid * * * * *$ & 9 & 0.1576 & 0.4637 \\
\hline$\left.\right|^{*}$ &. $\mid * * * *$ & 10 & 0.1315 & 0.3886 \\
\hline$\left.\right|^{*}$ &. $\mid * * *$ & 11 & 0.1053 & 0.292 \\
\hline$\left.\right|^{*}$ &.$\left.\right|^{* *}$ & 12 & 0.0702 & 0.2079 \\
\hline. $\mid$ &.$\left.\right|^{*}$. & 13 & 0.0351 & 0.0967 \\
\hline. $\mid$ &. $\mid$ & 14 & 0 & 0 \\
\hline$\cdot \mid$ &. $\mid$ & 15 & 0 & 0 \\
\hline$\cdot \mid \cdot$ &. $\mid$ & 16 & 0 & 0 \\
\hline$\cdot \mid$ &. $\mid$ & 17 & 0 & 0 \\
\hline$\cdot \mid$ &. $\mid$ & 18 & 0 & 0 \\
\hline$\cdot \mid$ &. $\mid$ & 19 & 0 & 0 \\
\hline$\cdot \mid$ &. $\mid$ & 20 & 0 & 0 \\
\hline$\cdot \mid$ & .1. & 21 & 0 & 0 \\
\hline$\cdot \mid$ &. $\mid$ & 22 & 0 & 0 \\
\hline$\cdot \mid \cdot$ &. $\mid$ & 23 & 0 & 0 \\
\hline$\cdot \mid \cdot$ &. $\mid$ & 24 & 0 & 0 \\
\hline$\cdot \mid \cdot$ &. $\mid$ & 25 & 0 & 0 \\
\hline. $\mid$ &. $\mid$. & 26 & 0 & 0 \\
\hline. $\mid$ &. $\mid$ & 27 & 0 & 0 \\
\hline. $\mid$ &. $\mid$ & 28 & 0 & 0 \\
\hline. $\mid$ &. $\mid$ & 29 & 0 & 0 \\
\hline. $\mid$ &. $\mid$ & 30 & 0 & 0 \\
\hline. $\mid$ &. $\mid$ & 31 & 0 & 0 \\
\hline. $\mid$ & $.1 . \quad \mid$ & 32 & 0 & 0 \\
\hline
\end{tabular}

Table 4 is indicated the covariance of indicator and their relationship of individual indicators. likewise, GVA, CPIAD, GDPPC and TR with MTG have shown the significant effect on investment and implemented policies. So therefore, the relationship of IGD and TS the implanted policies and its implication of trade in Africa.

Table 7: Maximum factors

Factor Method: Maximum Likelihood

Covariance Analysis: Ordinary Correlation

Sample (adjusted): 20052017

Included observations: 65 after adjustments

Balanced sample (list wise missing value deletion)

Number of factors: Minimum average partial

Prior communalities: Squared multiple correlation

Convergence achieved after 7 iterations

\section{Loadings}




\begin{tabular}{|c|c|c|c|c|c|}
\hline & $\mathrm{F} 1$ & Communality & Uniqueness & & \\
\hline CPIAD & 0.332776 & 0.11074 & 0.88926 & & \\
\hline CPIAQ & 0.598787 & 0.358546 & 0.641454 & & \\
\hline GDPPC & 0.955697 & 0.913357 & 0.086643 & & \\
\hline GVA & 1 & 1 & 0 & & \\
\hline IGD & 0.308166 & 0.094966 & 0.905034 & & \\
\hline MEL & 0.137412 & 0.018882 & 0.981118 & & \\
\hline MTG & 0.308655 & 0.095268 & 0.904732 & & \\
\hline TR & 0.327268 & 0.107104 & 0.892896 & & \\
\hline TS & 0.549849 & 0.302334 & 0.697666 & & \\
\hline Factor & Variance & Cumulative & Difference & Proportion & Cumulative \\
\hline $\mathrm{F} 1$ & 3.001197 & 3.001197 & --- & 1 & 1 \\
\hline \multirow[t]{2}{*}{ Total } & 3.001197 & 3.001197 & & 1 & \\
\hline & Model & Independence & Saturated & & \\
\hline Discrepancy & 3.877421 & 7.577025 & 0 & & \\
\hline $\begin{array}{l}\text { Chi-square } \\
\text { statistic }\end{array}$ & 248.155 & 484.9296 & --- & & \\
\hline $\begin{array}{l}\text { Chi-square prob. } \\
\text { Bartlett chi- }\end{array}$ & 0 & 0 & --- & & \\
\hline $\begin{array}{l}\text { square } \\
\text { Bartlett }\end{array}$ & 230.7066 & 455.8843 & --- & & \\
\hline probability & 0 & 0 & --- & & \\
\hline Parameters & 18 & 9 & 45 & & \\
\hline $\begin{array}{l}\text { Degrees-of- } \\
\text { freedom }\end{array}$ & 27 & 36 & --- & & \\
\hline
\end{tabular}

Warning: Heywood solution (uniqueness estimates are non-positive).

Results should be interpreted with caution.

Table 8 shows the padroni test of individual indicators of CPIAD and IGD with GVA within 6-1 ranking, the computed results is indicated the stationary issue in nonstationary level. The probability of test is indicated the turn over period 1960-2018. Table 9

Table 8: Correlate

$\begin{array}{lrllrlrl} & \text { CPIAD } & \text { CPIAQ } & \text { GDPPC } & \text { GVA } & \text { IGD } & \text { MEL } & \text { MTG } \\ & & & -2.83 \mathrm{E}- & - & & \\ \text { CPIAD } & -3.22 \mathrm{E}-15 & 0.573707104 & 0.087368372 & 15 & 0.129501948 & 0.246595646 & 0.24832 \\ & & & -2.78 \mathrm{E}- & - & & \\ \text { CPIAQ } & 0.573707104 & -4.66 \mathrm{E}-15 & 0.169391678 & 15 & 0.000874664 & 0.077150599 & 0.11374 \\ & - & - & & 3.33 \mathrm{E}- & - & & \\ \text { GDPPC } & 0.087368372 & 0.169391678 & 2.90 \mathrm{E}-09 & 16 & 0.041192064 & 0.009764396 & 0.01463\end{array}$




\begin{tabular}{|c|c|c|c|c|c|c|c|}
\hline GVA & $-2.83 E-15$ & $-2.78 \mathrm{E}-15$ & $3.33 \mathrm{E}-16$ & $\begin{array}{r}4.44 \mathrm{E}- \\
16\end{array}$ & $3.89 \mathrm{E}-16$ & $-5.55 \mathrm{E}-17$ & \\
\hline & - & - & 年 & $3.89 \mathrm{E}-$ & & $x^{2}+2$ & \\
\hline \multirow[t]{2}{*}{ IGD } & 0.129501948 & 0.000874664 & 0.041192064 & 16 & $4.44 \mathrm{E}-16$ & 0.097001772 & 0.02437 \\
\hline & & & & $5.55 \mathrm{E}-$ & - & & \\
\hline MEL & 0.246595646 & 0.077150599 & 0.009764396 & 17 & 0.097001772 & $-1.11 \mathrm{E}-16$ & 0.15252 \\
\hline MTG & 0.248323602 & 0.113747569 & 0.014630985 & 0 & 0.024374437 & 0.152526961 & -2.00 \\
\hline & & & & $7.22 \mathrm{E}-$ & & & \\
\hline $\mathrm{TR}$ & 0.117709958 & 0.070178457 & 0.046287995 & 16 & 0.12577333 & 0.106828207 & 0.69035 \\
\hline & & 85 & 38 & $1.11 \mathrm{E}-$ & 142 & & \\
\hline
\end{tabular}

Table 9: Fitness summary

Goodness-of-fit Summary

Factor: Untitled

Parameters

Degrees-of-freedom

Parsimony ratio

Absolute Fit Indices

Discrepancy

Chi-square statistic

Chi-square probability

Bartlett chi-square statistic

Bartlett probability

Root mean sq. reside.

(RMSR)

Akaike criterion

Schwarz criterion

Hannan-Quinn criterion

Expected cross-validation

(ECVI)

Generalized fit index (GFI)

Adjusted GFI

Non-centrality parameter

Gamma Hat

McDonald Non-centrally

Root MSE approximation

Incremental Fit Indices

$\begin{array}{rrrr}\text { Model } & \text { Independence } & \text { Saturated } \\ 18 & 9 & & 45 \\ 27 & 36 & --- & \\ 0.75 & 1 & --- & \end{array}$

$\begin{array}{rrlr}\text { Model } & \text { Independence } & \text { Saturated } \\ 3.877421 & 7.577025 & & 0 \\ 248.155 & 484.9296 & --- & \\ 0 & 0 & --- & \\ 230.7066 & 455.8843 & --- & \\ 0 & 0 & --- & \\ & & & \\ 0.176065 & 0.362026 & & 0 \\ 2.986999 & 6.352763 & & 0 \\ 2.083792 & 5.148487 & & 0 \\ 2.630626 & 5.877599 & & 0 \\ & & & \\ 4.439921 & 7.858275 & 1.40625 \\ 0.672501 & 0.488161 & & 1 \\ 0.454168 & 0.146935 & --- & \\ 221.155 & 448.9296 & --- & \\ 0.126405 & 0.066538 & --- & \\ 0.17768 & 0.029979 & --- & \\ 0.357747 & 0.441416 & --- & \end{array}$

Model 


$\begin{array}{ll}\begin{array}{l}\text { Bollen Relative (RFI) } \\ \text { Bentler-Bonnet Normed }\end{array} & 0.317688 \\ \begin{array}{l}\text { (NFI) } \\ \text { Tucker-Lewis Non-Normed }\end{array} & 0.488266 \\ \text { (NNFI) } & 0.343164 \\ \text { Bollen Incremental (IFI) } & 0.517055 \\ \text { Bentler Comparative (CFI) } & 0.507373\end{array}$

\section{CONCLUSIONS}

The above research is proved that investment in these western African countries not only to develop the individual region or society, it creating effect on the entire African state with huge monitoring polices. The gross value of debts and public administration is controlled the development objective of entire state with strategic and planned environment for state and reduce the level of inflation in small and enterprise section. The monitoring policies in developing countries is one of the important issue and influence factor in each individual state. Therefore, the impact of monetary policies on GDP per capita reflect the exchange rate in developing countries and generalized method of covariance by the probability level of linear value, where the highest mean deviation is directly affect the monetary integration and implication of trade in African countries. the integration of value has been analyzed by the CPIAD, IGD and TS. The above results estimated the coefficient of all indicators with $95 \%$ confidence interval. In addition, Wald test confirm the validity of the instrument by absence of serial autocorrelation in $1^{\text {st }}$ order. The estimation shows the monetary integration in African states. Therefore, the functioning of the foreign exchange and their implication in trade constantly shows the significant effects on proxy monitoring policies. The results reflect the debt policies, public administration with regional trade, GDP per capita, service in trade, trade of individual, merchandise trade, and export of low income economy. The stability of model is indicated the strategic policies so the results is conducting by the regression. It's necessary for the individual state to reduce the economy dependency in export and oil sources, to prevent the equity of public administration, trade in service and merchandise trade. The fluctuation of monetary policies and implication review the sector of currency policies in trade and investment. Furthermore, the above per-capita results are heighted the trade services and merchandise trade with different level of GDP. The gross development product need strategic techniques for development and entire export so therefore the one corner has been solving with monitoring policies and premeditated planed.

\section{ACKNOWLEDGEMENTS}

I would like to acknowledge the financed by the and thanks to supervisor for methodology and interpretatio

\section{REFERENCES}


Abid, M. (2017). Does economic, financial and institutional developments matter for environmental quality? A comparative analysis of EU and MEA countries. Journal of Environmental Management, 188, 183-194. doi:https://doi.org/10.1016/j.jenvman.2016.12.007

Acheampong, A. O. (2018). Economic growth, $\mathrm{CO} 2$ emissions and energy consumption: What causes what and where? Energy Economics, 74, 677-692. doi:https://doi.org/10.1016/j.eneco.2018.07.022

Adom, P. K., \& Kwakwa, P. A. (2014). Effects of changing trade structure and technical characteristics of the manufacturing sector on energy intensity in Ghana. Renewable and Sustainable Energy Reviews, 35, 475-483. doi:https://doi.org/10.1016/j.rser.2014.04.014

Ahmed, K., Bhattacharya, M., Shaikh, Z., Ramzan, M., \& Ozturk, I. (2017). Emission intensive growth and trade in the era of the Association of Southeast Asian Nations (ASEAN) integration: An empirical investigation from ASEAN-8. Journal of Cleaner Production, 154, 530-540. doi:https://doi.org/10.1016/j.jclepro.2017.04.008

Ahmed, K., Bhattacharya, M., Shaikh, Z., Ramzan, M., \& Ozturk, I (2017). Emission intensive growth and trade in the era of the Association of Southeast Asian Nations (ASEAN) integration: an empirical investigation from ASEAN-8. Journal of Cleaner Production, 154, 530-540. doi:https://doi.org/10.1016/j.jclepro.2017.04.008

Al-Mulali, U., Ozturk, I., \& Solarin, S. A. (2016). Investigating the environmental Kuznets curve hypothesis in seven regions: The role of renewable energy. Ecological Indicators, 67, 267-282. doi:https://doi.org/10.1016/j.ecolind.2016.02.059

Apergis, N., \& Ozturk, I. (2015). Testing Environmental Kuznets Curve hypothesis in Asian countries. Ecological Indicators, 52, 16-22. doi:https://doi.org/10.1016/j.ecolind.2014.11.026

Asongu, S. A., Folarin, O. E., \& Biekpe, N. (2019). The long run stability of money demand in the proposed West African monetary union. Research in International Business and Finance, 48, 483-495. doi:https://doi.org/10.1016/j.ribaf.2018.11.001

Awad, A., \& Abugamos, H. (2017). Income-carbon Emissions Nexus for Middle East and North Africa Countries: A Semi-parametric Approach,. International Journal of Energy Economics and Policy, 7(2).

Aydin, M. (2019). The effect of biomass energy consumption on economic growth in BRICS countries: A countryspecific panel data analysis. Renewable Energy, 138, 620-627. doi:https://doi.org/10.1016/j.renene.2019.02.001

Bekun, F. V., Emir, F., \& Sarkodie, S. A. (2019). Another look at the relationship between energy consumption, carbon dioxide emissions, and economic growth in South Africa. Science of The Total Environment, 655, 759-765. doi:https://doi.org/10.1016/j.scitotenv.2018.11.271

Bensassi, S., \& Jarreau, J. (2019). Price discrimination in bribe payments: Evidence from informal cross-border trade in West Africa. World Development, 122, 462-480. doi:https://doi.org/10.1016/j.worlddev.2019.05.023

Bo, N. A. C. B. P. S. (2015). Factors in the cross-cultural adaptation of African students in Chinese universities. Journal of Research in International Education, 14(2), 98-113.

Button, K., Martini, G., Scotti, D., \& Volta, N. (2019). Airline regulation and common markets in Sub-Saharan Africa. Transportation Research Part E: Logistics and Transportation Review, 129, 81-91. doi:https://doi.org/10.1016/j.tre.2019.07.007

Cham, T. (2016). Does monetary integration lead to an increase in FDI flows? An empirical investigation from the West African Monetary Zone (WAMZ). Borsa Istanbul Review, 16(1), 9-20. doi:https://doi.org/10.1016/j.bir.2016.01.002

Cheng, C., Ren, X., Wang, Z., \& Yan, C. (2019). Heterogeneous impacts of renewable energy and environmental patents on $\mathrm{CO} 2$ emission - Evidence from the BRIICS. Science of The Total Environment, 668, 1328-1338. doi:https://doi.org/10.1016/j.scitotenv.2019.02.063

Coleman, S. (2010). Inflation persistence in the Franc zone: Evidence from disaggregated prices. Journal of Macroeconomics, 32(1), 426-442. doi:https://doi.org/10.1016/j.jmacro.2009.08.002

Dong, B., Wang, F., \& Guo, Y. (2016). The global EKCs. International Review of Economics \& Finance, 43, 210-221. doi:https://doi.org/10.1016/j.iref.2016.02.010

Du, G., Liu, S., Lei, N., \& Huang, Y. (2018). A test of environmental Kuznets curve for haze pollution in China: Evidence from the penal data of 27 capital cities. Journal of Cleaner Production, 205, 821-827. doi:https://doi.org/10.1016/j.jclepro.2018.08.330

Du, J., \& Zhang, Y. (2018). Does One Belt One Road initiative promote Chinese overseas direct investment? China Economic Review, 47, 189-205. doi:https://doi.org/10.1016/j.chieco.2017.05.010

Grossman G, K. A. (1995). Economic growth and the environment. Quarterly Journal of Economics, 100(2), 353377. 
Harding, J. W. a. J. M. H. (2007). Generalized Linear Models and Extensions (2nd ed.).

Harvey, S. K., \& Cushing, M. J. (2015). Is West African Monetary Zone (WAMZ) a common currency area? Review of Development Finance, 5(1), 53-63. doi:https://doi.org/10.1016/j.rdf.2015.05.001

Im, K. S., Pesaran, M. H., \& Shin, Y. (2003). Testing for unit roots in heterogeneous panels. Journal of Econometrics, 115(1), 53-74. doi:https://doi.org/10.1016/S0304-4076(03)00092-7

Keho, Y. (2017). Revisiting the Income, Energy Consumption and Carbon Emissions Nexus: New Evidence from Quantile Regression for Different Country Groups. International Journal of Energy Economics and Policy, $7(3), 356-363$.

Kong, Y., \& Khan, R. (2019). To examine environmental pollution by economic growth and their impact in an environmental Kuznets curve (EKC) among developed and developing countries. PloS one, 14(3). doi:https://doi.org/10.1371/journal.pone.0209532

MengYun, W., Imran, M., Zakaria, M., Linrong, Z., Farooq, M. U., \& Muhammad, S. K. (2018). Impact of terrorism and political instability on equity premium: Evidence from Pakistan. Physica A: Statistical Mechanics and its Applications, 492, 1753-1762. doi:https://doi.org/10.1016/j.physa.2017.11.095

Mikayilov, J. I., Hasanov, F. J., \& Galeotti, M. (2018). Decoupling of CO2 emissions and GDP: A time-varying $\begin{array}{llll}\text { cointegration } \quad \text { Indicators, } & \text { 6cological 95 }\end{array}$ doi:https://doi.org/10.1016/j.ecolind.2018.07.051

Osabutey, E. L. C., \& Jackson, T. (2019). The impact on development of technology and knowledge transfer in Chinese MNEs in sub-Saharan Africa: The Ghanaian case. Technological Forecasting and Social Change, 148, 119725. doi:https://doi.org/10.1016/j.techfore.2019.119725

Perron, P. (1988). Testing for a Unit Root in Time Series Regression. Biometrika, 75(2), 335-346.

Riaz, A., Husain, S., Yousafzai, M. T., Nisar, I., Shaheen, F., Mahesar, W., . . Ali, A. (2018). Reasons for nonvaccination and incomplete vaccinations among children in Pakistan. Vaccine, 36(35), 5288-5293. doi:https://doi.org/10.1016/j.vaccine.2018.07.024

Saqib, S. E., Ahmad, M. M., \& Amezcua-Prieto, C. (2018). Economic burden of tuberculosis and its coping mechanism at the household level in Pakistan. The Social Science Journal, 55(3), 313-322. doi:https://doi.org/10.1016/j.soscij.2018.01.001

Schwerhoff, G., \& Sy, M. (2017). Financing renewable energy in Africa - Key challenge of the sustainable development goals. Renewable and Sustainable Energy Reviews, 75, 393-401. doi:https://doi.org/10.1016/j.rser.2016.11.004

Sinha, A., \& Shahbaz, M. (2018). Estimation of Environmental Kuznets Curve for CO2 emission: Role of renewable energy generation in India. Renewable Energy, 119, 703-711. doi:https://doi.org/10.1016/j.renene.2017.12.058

Tsao, L., Slater, S. E., Doyle, K. P., Cuong, D. D., Khanh, Q. T., Maurer, R., . . Krakauer, E. L. (2019). Palliative Care-Related Knowledge, Attitudes, and Self-Assessment Among Physicians in Vietnam. Journal of Pain and Symptom Management. doi:https://doi.org/10.1016/j.jpainsymman.2019.08.001

Yaya, O. S., Ling, P. K., Furuoka, F., Rose Ezeoke, C. M., \& Jacob, R. I. (2019). Can West African countries catch up with Nigeria? Evidence from smooth nonlinearity method in fractional unit root framework. International Economics, 158, 51-63. doi:https://doi.org/10.1016/j.inteco.2019.02.004

Zhang, Q., Liao, H., \& Hao, Y. (2018). Does one path fit all? An empirical study on the relationship between energy consumption and economic development for individual Chinese provinces. Energy, 150, 527-543. doi:https://doi.org/10.1016/j.energy.2018.02.106

Zhao, X., \& Kim, Y. (2009). Is the CFA Franc Zone an Optimum Currency Area? World Development, 37(12), 18771886. doi:https://doi.org/10.1016/j.worlddev.2009.03.011

. In the twentieth century, the economists of BIS1 